\title{
Amphibia, Anura, Microhylidae, Myersiella microps (Duméril and Bibron, 1841): New records and geographic distribution
}

\section{map}

\author{
Marco Antônio de Amorim Peixoto ${ }^{1 *}$, João Victor Andrade Lacerda ${ }^{1}$, Carla da Silva Guimarães ${ }^{1}$, \\ Bruno Teixeira ${ }^{3}$, Emanuel Teixeira da Silva ${ }^{2}$ and Renato Neves Feio ${ }^{1}$ \\ 1 Universidade Federal de Viçosa, Departamento de Biologia Animal, Museu de Zoologia “João Moojen” Vila Giannetti, 32, campus universitário. \\ CEP 36570-000. Viçosa, MG, Brazil. \\ 2 Centro Universitário de Caratinga, Centro de Estudos em Biologia. Rua Niterói, s/n, Bairro Nossa Senhora das Graças. CEP 35300-354. Caratinga, \\ MG, Brazil. \\ 3 Bioma Meio Ambiente Ltda., Alameda do Ingá, 840, Vale do Sereno. CEP 34000-000, Nova Lima, MG, Brazil \\ * Corresponding author. E-mail: marcopeixoto@yahoo.com.br
}

\begin{abstract}
Myersiella microps (Duméril and Bibron, 1841) is considered data deficient (DD) in the State of Minas Gerais, Southeastern Brazil. Herein we provide new records and a geographic distribution map of this poorly known species. These data provide valuable information for a conservation status assessment of M. microps.
\end{abstract}

The frog genus Myersiella Carvalho, 1954 is monotypic and its representative is Myersiella microps (Duméril and Bibron, 1841). Myersiella microps (Figure 1) is found in the leaf litter and under fallen tree trunks and rocks of primary and secondary forests (Dixo and Verdade 2006). This species have a direct development, laying eggs in the leaf litter (Izecksohn and Carvalho-e-Silva 2001; Haddad and Prado 2005; Haddad et al. 2008). Currently, this species is reported for areas of low and moderate elevation $(1100 \mathrm{~m}$ asl) of the Brazilian Atlantic rainforest along the state of Espírito Santo, Rio de Janeiro, São Paulo, and Minas Gerais (Hartmann et al. 2002; Frost 2011)

In the state of Minas Gerais, this species was first recorded at the Estação Biológica de Caratinga (currently Reserva Particular do Patrimônio Natural (RPPN) Feliciano Miguel Abdala) municipality of Caratinga (Feio et al. 2003). Another state record was made for the municipality of Cristina, west portion of the Mantiqueira Moutain Range (Martins et al. 2004; Figure 2). The geographic distribution of $M$. microps in the state of Minas Gerais is still poorly known. The conservation status of this frog is data deficient in the last available census (Fundação Biodiversitas 2007) and in broad context its conservation status is Least Concern (IUCN 2013).

We present new records in state Minas Gerais and a distribution map of $M$. microps, based on specimens housed in the following Brazilian collections: Museu de Zoologia João Moojen (MZUFV), Universidade Federal de Viçosa; Museu de Ciências Naturais (MCNAM) Pontifícia Universidade Católica de Minas Gerais; Museu Nacional (MNRJ) Universidade Federal do Rio de Janeiro and Museu de Zoologia da Universidade de São Paulo (MZUSP). Additional data were accessed from the database Species Link (Centro de Informação e Referência Ambiental www.splink.cria.org.br) and literature records.

Herein, we add seven new localities to the distribution of Myersiella microps in Minas Gerais (Figure 2). Nine specimens were collected in the Mantiqueira Mountain
Range: municipalities of Andrelândia (MNCAM-12628), Bocaina de Minas (MNRJ 43840), Cataguases (MZUFV 8934-38) and Lambari (MZUFV 8404-05). These records certify the presence of this species in the central portion of this mountain range. Four others specimens, from the municipalities of Itabira (MNCAN 16980-81) and São Gonçalo do Rio Abaixo (MNRJ 52276-77), represent the first records for this species in the Espinhaço Mountain Range, a transition area between the Atlantic rainforest and the Cerrado (Ab'Saber 1977). A recent overview of anuran distribution along the Espinhaço had not assigned M. microps to this mountain range (Leite et al. 2008).

The new localities here presented fill up an extensive gap between the two previous known records for Myersiella microps in Minas Gerais. Furthermore the species is reported for the first time in the Espinhaço Mountain Range. These data may be used as a support for an assessment of the conservation status of M. microps in the state of Minas Gerais.

The lack of studies on Myersiella and its distribution in different mountain chains are an indication that further work is needed for the real understanding of the taxonomy of this genus.

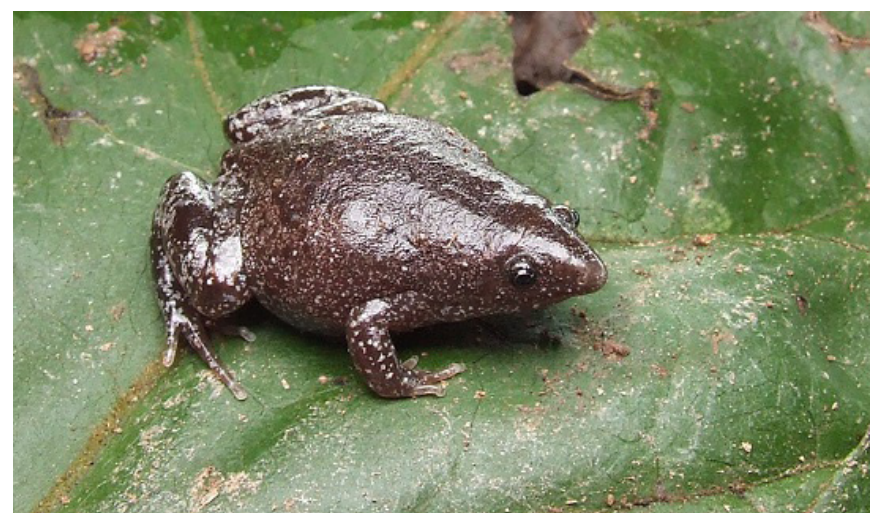

FIGURE 1. Myersiella microps (MZUFV 8000) collected in the municipality of Ipanema, state of Minas Gerais, Brazil. Photo by D.J. Santana. 


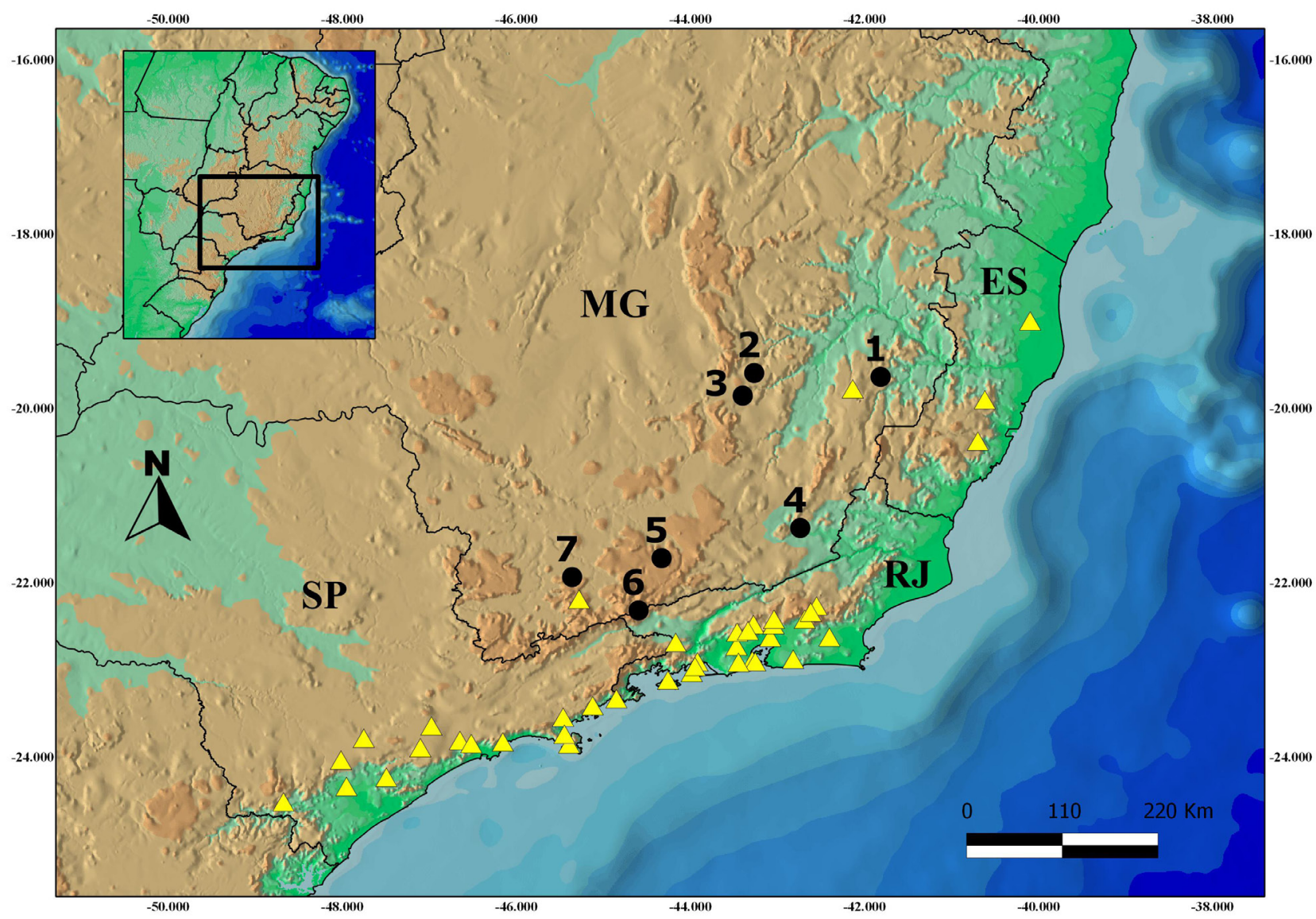

FigURE 2. Geographic distribution map of Myersiella microps and new records in the state of Minas Gerais, Brazil (yellow triangles $=$ records from literature and collections; black circle = new records): (1) Ipanema; (2) Itabira; (3) São Gonçalo do Rio Abaixo; (4) Cataguases; (5) Andrelândia; (6) Bocaina de Minas; (7) Lambari. Map by S.J. Teixeira.

ACKNOWLEDGMENTS: We are grateful to L. Nascimento (MNACN), Taran Grant (MZUSP) and J.P. Pombal Jr. (MNRJ) for allowing us to examined preserved specimens under their care. H.C. Costa, P. Peloso and R.B. Ferreira for helpful insights on early versions of the manuscript. B. Oliveira for help with English version. J.V. Lacerda is grateful to Capes for his Msc. Scholarship. C.S. Guimarães is grateful to Fapemig for his current scholarship. We would like to thank S.J. Teixeira for kindly drawing the map. We are grateful to D.J. Santana for kindly providing us with the photo of M. microps.

\section{LITERATURE CITED}

Ab'Saber, A.N. 1977. Os domínios morfoclimáticos na América do Sul. Primeira aproximação. Geomorfologica 52: 1-21.

Centro de Informação e Referência Ambiental, 2013. SpeciesLink. Versão: 2.0 (Maio de 2010). Electronic Database accessible at http://splink. cria.org.br. São Paulo, São Paulo, Brazil. Captured on 28 June 2013.

Dixo, M. and V.K. Verdade. 2006. Herpetofauna de serapilheira da Reserva Florestal de Morro Grande, Cotia (SP). Biota Neotropica 6(2): 1-20.

Feio, R.N., J. Cassimiro and C.A.G. Cruz. 2003. Myersiella microps. Herpetological Review 34(3): 259.

Frost, D. R. 2011. Amphibian Species of the World: an Online Reference. Version 5.5 (31 January, 2011). Electronic Database accessible at http://research.amnh.org/vz/herpetology/amphibia. American Museum of Natural History, New York, USA. Captured on 12 august 2012.

Fundação Biodiversitas. 2007. Revisão das listas das espécies da flora e da fauna ameaçadas de extinção do estado de Minas Gerais. Relatório Final, Volume 3 (Resultados: Lista Vermelha da Fauna de Minas Gerais). Electronic Database accessible at http://www.biodiversitas. org.br/listas-mg/lista_faunamg.asp. Belo Horizonte, Minas Gerais, Brazil. Captured on 18 June 2012.

Haddad, C.F.B and C.P.A. Prado. 2005. Reproductive Modes in the frogs and their Unexpected Diversity in the Atlantic Forest of Brazil. BioScience 55(3): 207-217.

Haddad, C.F.B., L.F. Toledo and C.P.A. Prado. 2008. Anfíbios da Mata Atlântica: Guia dos anfíbios anuros da Mata Atlântica. São Paulo: Editora Neotrópica. 200p.

Hartmann, M.T., P.A. Hartmann and C.F.B. Haddad. 2002. Advertisement Calls of Chiasmocleis carvalhoi, Chiasmocleis mehelyi, and Myersiella microps (Microhylidae). Journal of Herpetology 36( 3): 509-511.
Izecksohn, E. and S.P. Carvalho-e-Silva. 2001. Anfíbios do município do Rio de Janeiro. Rio de janeiro: Editora UFRJ. $148 \mathrm{p}$.

Leite, F.S.F., F.A. Juncá and P.C. Eterovick. 2008. Status do conhecimento, endemismo e conservação de anfíbios anuros da Serra do Espinhaço, Brasil. Megadiversidade 4(2): 158-176.

Martins, I. A. and A.F.B. Junqueira. 2004. Myersiella microps. Distribution extension. Herpetological Review 35(4): 405.

IUCN 2013. IUCN Red List of Threatened Species. Version 2013.1. <www. iucnredlist.org>. Downloaded on 02 July 2013.

RECEIVED: October 2013

ACCEPTED: August 2013

Published ONLINE: September 2013

Editorial RESPonsibility: Pedro L. V. Peloso

\section{APPENDIX 1. Specimens referenced}

ESPIRITO SANTO: Marechal Floriano (CFBH 4173); Santa Tereza (MBML 1694, MBML 3951-52, MNRJ 38409); MINAS GERAIS: Caratinga (MZUFV 4744-45); Cataguases (MZUFV 934, MZUFV 8935-38); Cristina (CFBH 9919, CFBH 9935 CFBH 14741, CFBH 15015); Ipanema (MZUFV 8000); Itatiaia (MNRJ 43840); Lambarí (MZUFV 8404-05); São Gonçalo do Rio Abaixo (MNRJ 52276-77); RIO DE JANEIRO: Cachoeira de Macacu (MNRJ 47970, MNRJ 48520); Grajaú (MNRJ 71507, MZUSP 82068-69); Ilha de Itacuruça (MNRJ 52475); Ilha Grande (MNRJ 51816-17); Magé (CFBH 275); Maricá (MNRJ 73105-06); Nova Friburgo (MNRJ 66222-23, MZUFV 5076); Nova Iguaçu (DZSJRP 711, ZUEC 3471-72, ZUEC 1243); Petrópolis (CFBH 13930); Rio Claro (MNRJ 76642); Tijuca (MNRJ 2150, MNRJ 40808, MZUSP 82066-67, MZUSP 82158-61); Tinguá (MZUSP 82054-58, MZUSP 82070); Xerém (MZUSP 82064); SÃO PAULO: Bertioga (MZUSP 136193-94); Caraguatatuba (MZUSP 150276, CFBH 1379); Cotia (MZUSP 132240-43, MZUSP 134398-04); Ilhabela (MNRJ 23664, CFBH 15213-14); Iporanga (MZUSP 75665); Juquitiba (MZUSP 134689-90, MZUSP 127619-22); Miracatu (MZUSP 82059); Piaçaguera (MZUSP 774); Pilar do Sul (CFBH 6111, CFBH 10006-07); São Miguel Arcanjo (MZUSP 136674-88, MZUSP 143618-23, MZUSP 143685-90, MZUSP147537-38); São Sebastião (MNRJ 44033, MZUSP 137383); Sete Barras (ZUEC 9749); Teresópolis (MNRJ 27543; MZUSP 82062-63); Ubatuba (CFBH 2527, CFBH 4042, CFBH 5661, CFBH 10803-10, MNRJ 48416). 